\title{
Pseudochrobactrum lubricantis sp. nov., isolated from a metal-working fluid
}

Correspondence
Peter Kämpfer
peter.kaempfer@umwelt.uni-
giessen.de

The genus Pseudochrobactrum was proposed by Kämpfer et al. (2006). At present, it comprises Pseudochrobactrum saccharolyticum, Pseudochrobactrum asaccharolyticum, Pseudochrobactrum kiredjianiae (Kämpfer et al., 2006, 2007) and Pseudochrobactum glaciei (Romanenko et al., 2008). Members of the genus can be clearly differentiated from members of the genera Ochrobactrum and Brucella on the basis of 16S rRNA gene sequence and $r e c A$ sequence data, as well as chemotaxonomic data (Kämpfer et al., 2006, 2007).

Strain KSS $7.8^{\mathrm{T}}$ was isolated from a metal-working fluid of a metal-processing company in Germany on nutrient agar at $30{ }^{\circ} \mathrm{C}$. Subcultivation was done on tryptone soy agar at $28{ }^{\circ} \mathrm{C}$ for $48 \mathrm{~h}$. On this agar, this organism grew also at 15$45{ }^{\circ} \mathrm{C}$, but not at 10 or $50{ }^{\circ} \mathrm{C}$. Growth at $30{ }^{\circ} \mathrm{C}$ was also observed on MacConkey agar and R2A agar (all from Oxoid).

Gram staining was performed as described by Gerhardt et al. (1994). Cell morphology was observed under a Zeiss

The GenBank/EMBL/DDBJ accession numbers for the 16S rRNA gene sequence and the recA sequence of strain KSS $7.8^{\top}$ are FM209496 and FM211811, respectively. light microscope at $\times 1000$, with cells grown for 3 days at $30{ }^{\circ} \mathrm{C}$ on nutrient agar. The $16 \mathrm{~S}$ rRNA gene was analysed as described previously (Kämpfer et al., 2003). Sequence analysis and similarity calculations were carried out by using the software programs Bionumerics v. 4.0 (Applied Maths BVBA) and MEGA v. 3.1 (Kumar et al., 2004). The sequenced length of the 16S rRNA gene was $1401 \mathrm{bp}$ (GenBank accession no. FM209496) for strain KSS $7.8^{\mathrm{T}}$. Sequence similarities to the three most closely related Pseudochrobactrum species were $99.8 \%$ to $P$. saccharolyticum CCUG $33852^{\mathrm{T}}, 99.8 \%$ to $P$. asaccharolyticum CCUG $46016^{\mathrm{T}}$ and $99.3 \%$ to P. kiredjianiae CCUG $49584^{\mathrm{T}}$. A lower similarity of $96.2 \%$ was found to P. glaciei KMM $3858^{\mathrm{T}}$. The $16 \mathrm{~S}$ rRNA gene-based tree shown in Fig. 1 results from a neighbour-joining reconstruction using the Kimura two-parameter correction and 1000 resamplings for bootstrap analysis.

The partial recA sequence of strain KSS $7.8^{\mathrm{T}}$ was analysed as described previously (Scholz et al., 2006). The PCR was performed with primers RecA-PsOchro-f ( $5^{\prime}$-AAGGCTCTGGACGCGGCACT- $3^{\prime}$ ) and RecA-PsOchro-r (5'-CGCAAGGTCAGTTC AATCTCAT- ${ }^{\prime}$ ). recA sequence similarity with $P$. kiredjianiae CCUG $49584^{\mathrm{T}}$ was $89.2 \%$; it was 




Fig. 1. $16 \mathrm{~S}$ rRNA gene sequence-based phylogenetic neighbour-joining tree reconstruction, showing the affiliation of Pseudochrobactrum lubricantis KSS $7.8^{\top}$ to its closest relatives. The significance of each branch is indicated by a bootstrap value (\%) calculated for 1000 subsets. Bartonella henselae M40SHD was used as outgroup to construct a pseudo-rooted tree. Bar, 0.005 divergent residues per site.
$88.8 \%$ with P. saccharolyticum CCUG $33852^{\mathrm{T}}$ and $91.7 \%$ with $P$. asaccharolyticum CCUG $46016^{\mathrm{T}}$ within $743 \mathrm{nt}$. Lower similarity values were observed to Brucella melitensis NCTC $10094^{\mathrm{T}}(80.5 \%)$ and Ochrobactrum anthropi LMG $3331^{\mathrm{T}}(82.2 \%)$. Strain KSS $7.8^{\mathrm{T}}$ formed a separate branch in the phylogenetic tree of recA sequences (743 nt) (Fig. 2). The tree was constructed by using CLUSTREE neighbour-joining analysis (Higgins et al., 1996). The recA gene of P. glaciei KMM $3858^{\mathrm{T}}$ could not be amplified with the primers described above and hence was not included in the analysis.

The results of the fatty acid analysis are shown in Table 1 . Fatty acids were analysed according to Kämpfer \& Kroppenstedt (1996). The fatty acid profile of strain KSS $7.8^{\mathrm{T}}$ was mainly composed of $\mathrm{C}_{19: 0}$ cyclo $\omega 8 c(53.9 \%)$, $\mathrm{C}_{18: 1} \omega 7 c(29.1 \%), \mathrm{C}_{18: 0}(7.8 \%)$ and $\mathrm{C}_{16: 0}(4.5 \%)$ and showed a high similarity to the fatty acid profiles of all other Pseudochrobactrum species. Quinones and polar lipids were extracted by an integrated protocol as described previously (Tindall, 1990a, b; Altenburger et al., 1996); quinone composition was analysed by HPLC as reported by Stolz et al. (2007). Polyamines were extracted and analysed as reported previously (Busse \& Auling, 1988; Busse et al., 1997; Stolz et al., 2007). The quinone system of strain KSS $7.8^{\mathrm{T}}$ consisted of the major compound ubiquinone Q-10 (97\%) and minor amounts of Q-8, Q9 and Q-11 (0.7-1.9\%). The polar lipid profile (results not shown) consisted of the major compounds phosphatidylethanolamine, phosphatidylglycerol, diphosphatidylgly- cerol and phosphatidylcholine, moderate amounts of phosphatidylmonomethylethanolamine and unknown aminolipid AL1, and small to trace amounts of three unknown polar lipids (L3, L4 and L5) corresponding to the lipids shown for $P$. asaccharolyticum CCUG $46016^{\mathrm{T}}$ (Kämpfer et al., 2006). The polyamine pattern was as follows [in $\mu \mathrm{mol}(\mathrm{g} \text { dry weight })^{-1}$ ]: spermidine, 63.8; putrescine, 43.9; 1,3-diaminopropane, 0.7; spermine, 2.3. Both polar lipid profile and polyamine pattern are quite similar to those reported for other Pseudochrobactrum species and are in good agreement with the characteristics of the genus description (Kämpfer et al., 2006, 2007), although the unknown lipids L1 and L2 were not detectable in strain KSS $7.8^{\mathrm{T}}$.

Results of the physiological characterization are given in the species description and in Table 2. The methods used have been described previously (Kämpfer et al., 1991). The organism can be clearly differentiated from the other Pseudochrobactrum species on the basis of several tests.

DNA-DNA hybridization experiments were performed with strain KSS $7.8^{\mathrm{T}}$ and type strains of the three most closely related Pseudochrobactrum species by using the method described by Ziemke et al. (1998), except that for nick translation, $2 \mu \mathrm{g}$ DNA was labelled during a $3 \mathrm{~h}$ incubation at $15{ }^{\circ} \mathrm{C}$. Strain KSS $7.8^{\mathrm{T}}$ showed relatively low DNA-DNA similarity to $P$. asaccharolyticum CCUG $46016^{\mathrm{T}}$ (24.8\%), P. saccharolyticum CCUG 33852 (45.7\%) and P. kiredjianiae CCUG $49584^{\mathrm{T}}$ (40.9\%).

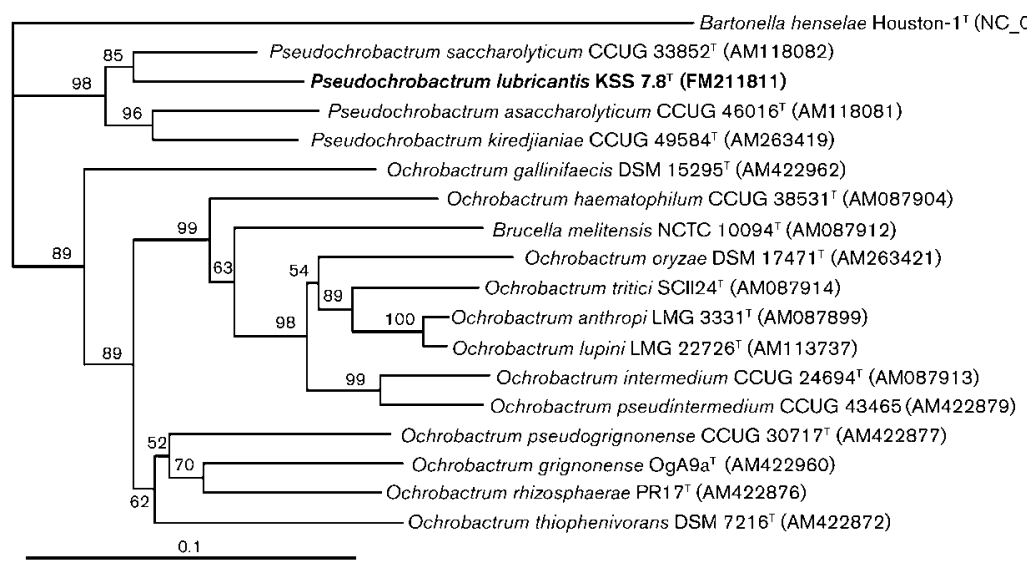

Fig. 2. Phylogenetic tree reconstruction with recA sequences (743 nt) using CLUSTREE neighbour-joining analysis (Higgins et al., 1996). The significance of each branch is indicated by a bootstrap value (\%) calculated for 1000 subsets. The tree was rooted by using the sequence of Bartonella henselae Houston- $1^{\top}$ as an outgroup. Bar, 0.1 divergent residues per site. 
Table 1. Major fatty acid compositions (\%) of type strains of Pseudochrobactrum species

Taxa: 1, strain KSS $7.8^{\mathrm{T}} ; 2$, P. kiredjianiae CCUG $49584^{\mathrm{T}} ; 3, P$. asaccharolyticum CCUG $46016^{\mathrm{T}}$; 4 , P. saccharolyticum CCUG $33852^{\mathrm{T}}$; 5, P. glaciei KMM $3858^{\mathrm{T}}$. All strains were grown on trypticase soy broth agar at $28{ }^{\circ} \mathrm{C}$ for $48 \mathrm{~h}$ prior to fatty acid analysis. Data were obtained in the present study except where indicated.

\begin{tabular}{|c|c|c|c|c|c|}
\hline Fatty acid & 1 & 2 & 3 & 4 & $5^{\star}$ \\
\hline \multicolumn{6}{|l|}{ Saturated: } \\
\hline $\mathrm{C}_{12: 0}$ & & & & 0.7 & \\
\hline $\mathrm{C}_{14: 0}$ & & & & & 0.6 \\
\hline $\mathrm{C}_{16: 0}$ & 4.5 & 2.8 & 5.5 & 1.9 & $8.9(5.4)$ \\
\hline $\mathrm{C}_{18: 0}$ & 7.8 & 7.7 & 11.0 & 7.4 & $5.5(4.4)$ \\
\hline \multicolumn{6}{|l|}{ Unsaturated $\dagger$ : } \\
\hline $\mathrm{C}_{18: 1} \omega 7 c$ & 29.1 & 33.4 & 74.9 & 74.6 & $31.2(41.5)$ \\
\hline $\mathrm{C}_{18: 3} \omega 6 c(6,9,12)$ & & & & 0.5 & \\
\hline 11-methyl- $\mathrm{C}_{18: 1} \omega 7 t$ & 1.8 & 1.0 & & & 1.0 \\
\hline $\mathrm{C}_{20: 1} \omega 7 c$ & & 0.8 & & & \\
\hline $\mathrm{C}_{20: 2} \omega 6,9 c$ & 1.4 & 0.9 & & & 0.9 \\
\hline \multicolumn{6}{|l|}{ Hydroxy: } \\
\hline $\mathrm{C}_{18: 0} 3-\mathrm{OH}$ & & & & & 0.6 \\
\hline Summed feature $3 \ddagger$ & & & 0.8 & & 1.6 \\
\hline \multicolumn{6}{|l|}{ Cyclo propane acids: } \\
\hline $\mathrm{C}_{17: 0}$ cyclo & & 0.5 & & & 1.0 \\
\hline $\mathrm{C}_{19: 0}$ cyclo $\omega 8 \mathrm{c}$ & 53.9 & 53.0 & 7.3 & 14.3 & $47.9(46.2)$ \\
\hline $\begin{array}{l}\text { Unknown (ECL } \\
14.959) \S\end{array}$ & 1.2 & & 0.6 & 0.9 & 0.9 \\
\hline
\end{tabular}

${ }^{\star}$ Data in parentheses are from Romanenko et al. (2008).

$\dagger$ The position of the double bond is located by counting from the methyl $(\omega)$ end of the carbon chain.

$\ddagger$ Summed features are groups of fatty acids that cannot be separated by GLC with the MIDI system. Summed feature 3 contains $\mathrm{C}_{16: 1} \omega 7 c$ and/or $\mathrm{C}_{15: 0}$ iso 2-OH.

$\S$ Unknown fatty acids have no name listed in the peak library file of the MIDI system and therefore cannot be identified. ECL, Equivalent chain length.

From the results of $16 \mathrm{~S}$ rRNA gene and recA sequencing and from the physiological characteristics, it is evident that strain KSS $7.8^{\mathrm{T}}$ is different from previously described species of the genus Pseudochrobactrum. For this reason, Pseudochrobactrum lubricantis sp. nov. is proposed to accommodate strain KSS $7.8^{\mathrm{T}}$.

\section{Description of Pseudochrobactrum lubricantis sp. nov.}

Pseudochrobactrum lubricantis [lu.bri.can'tis. L. v. lubricare to lubricate; N.L. n. lubricans -antis (from L. part. adj. lubricans) a lubricant; N.L. gen. n. lubricantis of/from a (coolant) lubricant].

Shares all characteristics listed in the genus description (Kämpfer et al., 2006). In addition, good growth occurs on R2A agar, tryptone soy agar, nutrient agar and MacConkey agar at $25-30{ }^{\circ} \mathrm{C}$. Beige, translucent and shiny colonies with
Table 2. Physiological characteristics of the type strains of Pseudochrobactrum species

Taxa: 1 , strain KSS $7.8^{\mathrm{T}} ; 2$, P. kiredjianiae CCUG $49584^{\mathrm{T}} ; 3, P$. asaccharolyticum CCUG $46016^{\mathrm{T}} ; 4$, P. saccharolyticum CCUG $33853^{\mathrm{T}}$; 5, P. glaciei KMM $3858^{\mathrm{T}}$. Data for strains 1 and 5 are from the present study; data for strains 2-4 are from Kämpfer et al. (2007), based on the same methods. +, Positive; -, negative; $(+)$, weakly positive. All strains were positive for hydrolysis of L-alanine- $p$-nitroanilide and Lproline- $p$-nitroanilide and weak hydrolysis of bis- $p$-nitrophenylphosphate. All strains were negative for hydrolysis of aesculin, $p$ nitrophenyl- $\beta$-D-galactopyranoside, $p$-nitrophenyl- $\beta$-D-glucuronide, $p$-nitrophenyl- $\alpha$-D-glucopyranoside, $p$-nitrophenyl- $\beta$-D-glucopyranoside, $p$-nitrophenylphosphorylcholine, $p$-nitrophenyl phenylphosphonate and 2-deoxythymidine- $5^{\prime}-p$-nitrophenylphosphate. All strains were also positive for assimilation of acetate, oxoglutarate, L-alanine, L-proline and L-serine. All strains (P. glaciei KMM $3858^{\mathrm{T}}$ was not included in the tests) were negative for assimilation of adonitol, p-arbutin, cellobiose, D-gluconate, i-inositol, maltose, D-maltitol, D-mannitol, $\alpha$-D-melibiose, D-sorbitol, salicin, trehalose, putrescine, L-phenylalanine, L-tryptophan, 3-hydroxybenzoate, trans-aconitate, adipate, citrate, itaconate, mesaconate, L-leucine, phenylacetate, suberate, azelate and 4-hydroxybenzoate.

\begin{tabular}{|lccccc|}
\hline Characteristic & $\mathbf{1}$ & $\mathbf{2}$ & $\mathbf{3}$ & $\mathbf{4}$ & $\mathbf{5}$ \\
\hline Assimilation of: & & & & & \\
L-Arabinose & - & - & - & + & - \\
D-Xylose & - & - & - & + & + \\
D-Mannose & + & - & - & + & $(+)$ \\
D-Glucose & + & + & - & + & $(+)$ \\
D-Fructose & + & - & - & + & + \\
DL-3-Hydroxybutyrate & - & - & - & + & - \\
D-Galactose & + & $(+)$ & - & + & + \\
Pyruvate, ornithine & + & - & - & + & - \\
D-Ribose, propionate, glutarate & + & + & - & + & - \\
Fumarate & + & + & - & + & - \\
DL-Lactate, L-malate & + & + & - & + & - \\
L-Rhamnose & - & + & - & - & - \\
4-Aminobutyrate, $\beta$-alanine & + & + & - & + & - \\
cis-Aconitate & $(+)$ & - & + & + & - \\
$N$-Acetyl-D-glucosamine & + & $(+)$ & - & + & + \\
L-Aspartate & + & $(+)$ & - & + & - \\
L-Histidine & + & - & - & + & + \\
\hline
\end{tabular}

entire edges form within $24 \mathrm{~h}$, with a diameter of approximately $2 \mathrm{~mm}$. Carbon-source utilization and hydrolysis of chromogenic substrates (including differentiating characters for all Pseudochrobactrum species) are indicated in Table 2. The major fatty acids are $\mathrm{C}_{18: 2} \omega 7 \mathrm{c}$ and $\mathrm{C}_{19: 0}$ cyclo $\omega 8 c$. The polar lipid profile consists of the major compounds phosphatidylethanolamine, phosphatidylglycerol, diphosphatidylglycerol and phosphatidylcholine, moderate amounts of phosphatidylmonomethylethanolamine and unknown aminolipid AL1, and small to trace amounts of three unknown polar lipids. Ubiquinone Q-10 is the major quinone. The polyamine pattern consists of the major compounds spermidine and putrescine and minor amounts of 1,3-diaminopropane and spermine. 
The type strain is KSS $7.8^{\mathrm{T}}$ (=CCUG $56963^{\mathrm{T}}=\mathrm{CCM}$ $7581^{\mathrm{T}}$ ), isolated from a water-mixed metal-working fluid.

\section{Acknowledgements}

The study was supported by a grant to P.K. by the Berufsgenossenschaft Metall Nord Süd - BGM (formerly Berufsgenossenschaft Metall Süd). The work of B. H. and H.-J. B. was supported by a Contract Research Project for the Bundeswehr Medical Service. We thank Dr L. A. Romanenko for kindly providing the type strain of Pseudochrobactrum glaciei.

\section{References}

Altenburger, P., Kämpfer, P., Makristathis, A., Lubitz, W. \& Busse, H.-J. (1996). Classification of bacteria isolated from a medieval wall painting. J Biotechnol 47, 39-52.

Busse, H.-J. \& Auling, G. (1988). Polyamine pattern as a chemotaxonomic marker within the Proteobacteria. Syst Appl Microbiol 11, 1-8.

Busse, H.-J., Bunka, S., Hensel, A. \& Lubitz, W. (1997). Discrimination of members of the family Pasteurellaceae based on polyamine patterns. Int J Syst Bacteriol 47, 698-708.

Gerhardt, P., Murray, R. G. E., Wood, W. A. \& Krieg, N. R. (editors) (1994). Methods for General and Molecular Bacteriology. Washington, DC: American Society for Microbiology.

Higgins, D. G., Thompson, J. D. \& Gibson, T. J. (1996). Using ClUSTAL for multiple sequence alignments. Methods Enzymol 266, 383-402.

Kämpfer, P. \& Kroppenstedt, R. M. (1996). Numerical analysis of fatty acid patterns of coryneform bacteria and related taxa. Can J Microbiol 42, 989-1005.

Kämpfer, P., Steiof, M. \& Dott, W. (1991). Microbiological characterization of a fuel-oil contaminated site including numerical identification of heterotrophic water and soil bacteria. Microb Ecol 21, 227-251.

Kämpfer, P., Dreyer, U., Neef, A., Dott, W. \& Busse, H.-J. (2003). Chryseobacterium defluvii sp. nov., isolated from wastewater. Int J Syst Evol Microbiol 53, 93-97.

Kämpfer, P., Rosselló-Mora, R., Scholz, H., Welinder-Olsen, C. \& Busse, H.-J. (2006). Description of Pseudochrobactrum gen. nov., with the two species Pseudochrobactrum asaccharolyticum sp. nov. and Pseudochrobactrum saccharolyticum sp. nov. Int J Syst Evol Microbiol 56, 1823-1829.

Kämpfer, P., Scholz, H., Huber, B., Thummes, K., Busse, H.-J., Maas, E. W. \& Falsen, E. (2007). Description of Pseudochrobactrum kiredjianiae sp. nov. Int J Syst Evol Microbiol 57, 755-760.

Kumar, S., Tamura, K. \& Nei, M. (2004). MEGA3: integrated software for molecular evolutionary genetics analysis and sequence alignment. Brief Bioinform 5, 150-163.

Romanenko, L. A., Tanaka, N., Frolova, G. M. \& Mikhailov, V. V. (2008). Pseudochrobactrum glaciei sp. nov., a novel sea ice isolate from Peter the Great Bay of the Sea of Japan. Int J Syst Evol Microbiol 58, 2454-2458.

Scholz, H. C., Tomaso, H., Al Dahouk, S., Witte, A., Schloter, M., Kämpfer, P., Falsen, E. \& Neubauer, H. (2006). Genotyping of Ochrobacterium anthropi by recA-based comparative sequence, PCRRFLP, and 16S rRNA gene analysis. FEMS Microbiol Lett 257, 7-16.

Stolz, A., Busse, H.-J. \& Kämpfer, P. (2007). Pseudomonas knackmussii sp. nov. Int J Syst Evol Microbiol 57, 572-576.

Tindall, B. J. (1990a). Lipid composition of Halobacterium lacusprofundi. FEMS Microbiol Lett 66, 199-202.

Tindall, B. J. (1990b). A comparative study of the lipid composition of Halobacterium saccharovorum from various sources. Syst Appl Microbiol 13, 128-130.

Ziemke, F., Höfle, M. G., Lalucat, J. \& Rosselló-Mora, R. (1998). Reclassification of Shewanella putrefaciens Owen's genomic group II as Shewanella baltica sp. nov. Int J Syst Bacteriol 48, 179-186. 